\title{
Insect conservation psychology
}

\author{
John P. Simaika ${ }^{1,2} \cdot$ Michael J. Samways $^{2}$
}

Received: 19 January 2017 / Accepted: 23 January 2018 / Published online: 21 February 2018

(c) The Author(s) 2018, corrected publication May 2018

\begin{abstract}
People seek connectedness with nature, as evidenced by 8 billion people per year visiting terrestrial parks alone. Yet the challenge is for people to appreciate and care for nature, including insects, on which we so crucially depend for so many services. Current environmental policy is often a dichotomy of mutually exclusive opposites: instrumental valuation vs. intrinsic valuation. This unhelpful division can be overcome by valuing nature through appreciation of spatial extent (local to global) relative to biological level (gene through population and species, to ecosystem) and understanding that human well-being is a two-way process of caring for nature $\leftrightarrow$ nature providing a well-being platform for us. However, human relationships with nature are complex, as they are with insects too. The human brain is not well equipped to deal with topics that are complex, seemingly far away in space and time, and are nebulous. These topics beget inaction by the public at large on, for example, global change. Neither are we well equipped to value insects, despite scientific understanding of their importance to our well-being. However, we are at least rising to the pollination crisis, as we can relate to the tangible bee and our food security. To improve insect conservation awareness and action, we need to engage insect conservation psychology. Citizen science and Red Listing are playing major roles here, as is the camera, which magnifies and makes insects more meaningful to us. Using insect conservation psychology, we are better able to instill a culture of personal and social responsibility, and so create political will to drive insect conservation from paper to action.
\end{abstract}

Keywords Environmental ethics $\cdot$ Biophilia $\cdot$ Biophobia $\cdot$ Utilitarian value $\cdot$ Intrinsic value $\cdot$ Complex issues $\cdot$ Rescuing the extinction of experience

\section{The need for a new psychology}

Psychology aims to understand human behaviour and promote human well-being, while in turn, conservation psychology aims to understand and promote human care for nature (Clayton and Myers 2009). Conservation psychology is also about recognizing our dependence on nature, not just to provide for us physically, but for understanding why and how it is so essential for our well-being. In short, it is a circular

The original version of this article was revised due to a retrospective Open Access order.

John P. Simaika

simaikaj@sun.ac.za

Michael J. Samways

samways@sun.ac.za

1 Department of Soil Science, Stellenbosch University, Stellenbosch, South Africa

2 Department of Conservation Ecology and Entomology, Stellenbosch University, Matieland 7602, South Africa process of caring for nature, and nature inadvertently caring for us.

We are not doing a good job of loving and protecting nature, especially insects, even in some of the most advanced of societies (Hallmann et al. 2017). Furthermore, how we view this current mass extinction crisis has huge ramifications about how we go about averting more extinction. There are three ways to view this mass extinction: (1) it is a loss of important resources (i.e. it is a mistake), (2) as interspecies genocide (i.e. it is a crime), and (3) as evidence that humanity is a cancer of the biosphere (i.e. it is an inevitability) (Cafaro 2015). Globally, we must admit that we are the root cause of all the current damage, including the collateral damage to many other species, especially whole-scale loss of insects, through our technological, economic and social advancement. Our view of nature and destruction of it is actually an extraordinary phenomenon: that we are doing so much harm to the very natural system on which we depend for our survival. 
Part of our problem is that we take nature and its provisions for granted. Not only that, we rarely stop to think that nature's interactions have been honed for over 4 billion years, leading to a complexity that is virtually beyond our full comprehension. Take a small ecosystem with a 1000 species. This is potentially half a million interactions. Then, to consider and appreciate all interactions in all ecosystems on earth is way beyond our comprehension. In turn, apart from the very coldest and the saltiest, all ecosystems have insects as part of their fabric, evolutionarily tuned for over 400 million years. Conserving this complexity calls for psychological tools to enable us to absorb it in our minds, and to find ways to conserve all these insects.

Today we wrestle with our relationship with nature. In former times, when our survival was so much more directly dependent on understanding the whims of climate and of nature to avert famine in particular, we prayed for exemption (Harari 2016). Today we irrigate extensively and we deliver food supplies to help alleviate famine. In turn, we understand disease better, and are more able to control it. Yet we seem not to be able to understand that insects are pivotal to the maintenance of many terrestrial and freshwater ecosystems as we know them. Part of this lack of appreciation and caring for insects is that they are much smaller than us, and are largely hidden in plain view (Samways and Böhm 2012).

Take current thinking in environmental policy, which is considered by some as a dichotomy of opposites, with instrumental valuation (that nature provides benefits and services for us) on the one hand, and intrinsic valuation on the other (simplistically, that in all aspects nature has value in and of itself, without necessarily any direct benefit to us). Justus et al. (2009) suggest that instrumental value has more currency for conservation action, which after all is a mission driven science. This instrumental approach, for example, is used in ecosystem service valuation (Costanza et al. 2016). In contrast, Batavia and Nelson (2017) argue that as conservationists we need to return to considering intrinsic value with deeper understanding, through turning such a generalized sentiment into reflecting on what is good, worth protecting, and how we ought to interact with the world around us.

How we value nature (Rolston 1994) now needs consolidating into a more cohesive action plan. This lies in the realm of conservation psychology, which, in turn, lies in the broader realm of environmental psychology, which aims to provide tools to facilitate better management and governance of the environment. This goes beyond the protection of species and ecosystems by engaging stakeholder and public audiences so that there is delivery of management objectives that meet both societal and ecological goals. This is possible, as shown by some of the examples in Walker-Springett et al. (2016).

The valuation approach that leads to conservation action has several dimensions. These dimensions can reconcile the perceived dichotomy of opposites (instrumental vs. intrinsic). This approach introduces a whole range of relational values (Chan et al. 2016) on how humans and the rest of nature interrelate. This reconciliation also comes about through appreciation of spatial extent (local to global) relative to biological level (gene through population and species, to ecosystem) (Pearson 2016).

As regards insects, and because of their huge complexity and our great lack of knowledge about them, we also need to reconcile and integrate scientific and ethical approaches for effective insect conservation (Samways 2017). This means that the actual doing of insect conservation relative to values also has spatial extent, from local (e.g. value of a local species, or a pond) to global (the pollinator crisis). Conservation action also has biological levels. These range from conserving specific evolutionarily significant units, through maintaining local pollinator networks, to conserving large-scale migrations, and global problems such as habitat fragmentation, the single most global threat to invertebrates (Gerlach et al. 2012). These different spatial scales, relating to both value and action, also have different psychologies associated with them, which range from the psychology of the individual human through to the sociology of human communities, from local to global.

\section{Connecting people with nature}

In addition to investigating value systems, there is perhaps a more urgent need to focus on understanding the human psyche and our response to nature i.e. conservation psychology. Connecting people with nature is already being done in some countries as part of government-sponsored health programmes (Burls 2007; IEEP et al. 2016). In part, this is due to the increasing recognition that contact with nature reduces medical costs and benefits local economies (Nilsson et al. 2010).

To achieve conservation goals, practitioners are incentivising social responsibility and awareness using a variety of tools from other disciplines, especially the social sciences, as conservation is as much a human science as it is a life science (Pearson 2016). By connecting people with insects through nature experiences, caring for insects in individuals and society at large can emerge (Samways 2015). This process is known as 'rescuing the extinction of experience', which in the case of insects, is especially significant for children who not only relate well to many insect characters but also are the pool from which future insect conservationists will be drawn (Samways 2007). 


\section{Empathy, caring, and insect conservation}

Human satisfaction links to greater feelings of empathy and caring (Weinstein et al. 2015). Connecting with nature promotes personal aims and choices that reflect caring and feelings of good health. These positive feelings include care of nature which supports beneficial decision making for the environment (Hoot and Friedman 2011; Zylstra et al. 2014). Connecting with nature also promotes caring for other people, especially poorer communities (Mitchell and Popham 2008).

In our technological society, people are interacting less with nature, show more extinction of experience, and know and understand less about nature. Consequently, they care less (Kahn and Kellert 2002). This suggests that the psychology behind moral behaviour, and the assignment of moral imperatives by human individuals to social problems, as well as the motivation for or against pro-social behaviour, is not trivial. This means that psychology could consequently influence the success or not of the conservation endeavour. Public opinion, and consequently demand, are powerful tools for the conservation cause, and are likely to engage decision makers and compel them to act (Weinstein et al. 2015).

\section{To like or not like insects}

One of the greatest challenges for improving the caring of insects is that many 'insects' are not 'nice' or 'useful', and are 'ugly'. This view has a bearing on the intrinsic vs. instrumental debate, and hinders application of value-pluralism (i.e. all the other values between the dichotomy) (MartínLópez and Montes 2015). The human relationship with nature is complex, but can be intuitively typified, using an integrative framework of values, also known as biophilia values (Kellert 1993). Importantly, biophilia is learned and not intrinsic, in contrast, biophobia, which is intrinsic (Simaika and Samways 2010).

There is a positive feedback mechanism associated with biophilia. Just looking at images of nature is beneficial to human health (Clark et al. 2014), and this makes learning and positive reinforcement easier. Images of iconic insects even find their way onto our clothing, home fabrics, and crockery, which suggests that we do enjoy at least some of them, and are willing to spend money on insect images that adorn ourselves, and our homes. This in turn, must surely imprint on children as well. This is an important indirect means of raising awareness of the joy of insects, albeit not actually conservation. It is though, at least a small step in the right conceptual direction.

Kellert's (1993) framework on biophilia values is integrative, that is, a spectrum of values from utilitarian to negativistic. Indeed, moralistic valuation (intrinsic value of nature) is not at the end of the spectrum, with dominionistic (mastery, physical control) and negativistic (fear, aversion, alienation) being the end-points (Table 1). Like Norton's (2000) universal earth ethic, Kellert's typology does not view utilitarianism as an opposite to intrinsic value, but incorporates both of them as part of the human relationship with nature. Indeed, Norton (2000) rejects the dichotomy of opposites, noting that humans value nature in many ways that range from entirely self-directed and consumptive values to spiritual and aesthetic values, to non-instrumental valuations. By accepting that a spectrum of attitudes exists, a pluralist and integrative arrangement emerges. This means that the biophilia value framework lends itself to a universal ethic for conserving biodiversity, with insects as the dominant component in terms of numbers of species (Simaika and Samways 2010). Acceptance that anyone may exhibit different attitudes in different situations is also an important part of this ethic. As such, the framework is not only

Table 1 Biophilia values as presented by Kellert (1993)

\begin{tabular}{|c|c|c|}
\hline Term & Definition & Function \\
\hline Utilitarian & Practical and material exploitation of nature & Physical sustenance and security \\
\hline Naturalistic & Satisfaction from direct experience or contact with nature & Curiosity, outdoor skills, mental/physical development \\
\hline Ecologistic-scientific & $\begin{array}{l}\text { Systematic study of structure, function, and relationship in } \\
\text { nature }\end{array}$ & Knowledge, understanding, observational skills \\
\hline Aesthetic & Physical appeal and beauty of nature & Inspiration, harmony, peace, security \\
\hline Symbolic & $\begin{array}{l}\text { Use of nature for metaphorical expression, language expressive } \\
\text { thought }\end{array}$ & Communication, mental development \\
\hline Humanistic & Strong affection, emotional attachment, "love" for nature & Group bonding, sharing, cooperation companionship \\
\hline Moralistic & Strong affinity, spiritual reverence, ethical concern for nature & Order and meaning in life, kinship and affiliational ties \\
\hline Dominionistic & Mastery, physical control, dominance of nature & Mechanical skills, physical prowess, ability to subdue \\
\hline Negativistic & Fear, aversion, alienation from nature & Security, protection, safety \\
\hline
\end{tabular}


about (explicit) categories, but also as dynamically changing (implicit) categories.

\section{Thinking global, acting local}

Human well-being combined with the conservation of nature is just the driver needed for taking conservation from thought to action. Together they also gain traction towards meeting the Sustainable Development Goals, agreed to by all 193 UN member states, especially as the Gross Domestic Product (GDP) has exacerbated inequality and damaged the environment of many countries, canceling out net benefits derived from improved GDP (Costanza et al. 2016). Accordingly, new metrics of human and ecosystem well-being are needed that combine insight from psychology and ecology to describe how the complex of natural, social, human and built assets can contribute to sustainable well-being, with the best system aiming at achieving the goal of a prosperous, equitable, and sustainable world (Bennett 2017).

Conservationists in the relatively species-poor Global North in particular are faced with staving off the extinction of experience (Samways 2007; Soga and Gaston 2016) and generational amnesia (Kahn and Kellert 2002). Thus their focus should be on (re-)connecting people with nature, perhaps already in primary school (Schlegel et al. 2015) and 'rewilding people' by rewilding landscapes (Navarro and Pereira 2012). Conservation in the Global South, where most biodiversity occurs, still faces barriers to social and economic justice and equality. These barriers have to be removed for conservation to be effective and socially just. Intergenerational issues are part of this new approach, with children and the elderly much more engaged in insect conservation awareness than economically-active adults (Suh and Samways 2001). Indeed, rewilding ourselves would instill a culture of responsibility on both a personal and a collective social level, for nature and all its insects.

\section{Our perceptions on a changing world}

Instigation of effective political agendas also depends on human will. Overall, people do not think that protecting natural resources is that important. As Kellstedt et al. (2008) explain, the reporting of statistics on the decline of nature is not effective for galvanizing the public into conservation action. This happens regardless of how people value nature. Why is this? The answer, on how best to conserve insects for example, may lie in understanding the human psyche. By understanding our own psyche better, conservationists could send out more finely tuned messages about the value and need for insect conservation, and so elicit positive outcomes.
Negative messages, such as those commonly seen in the media, such as icebergs breaking up, or people wearing masks to escape air pollution, can elicit defensive responses and lower peoples' openness to new information (Weinstein et al. 2015). These are behavioural responses which reduce tension (Roskos-Ewoldsen et al. 2004). In some circumstances, this can be coupled with other defensive reactions such as reactance and denial, and so have an even more negative effect (Weinstein et al. 2015).

Yet interestingly, the pollinator crisis (Potts et al. 2010) has stimulated huge efforts towards correcting it in many parts of the world (Ferrier et al. 2016). This has also gone hand in hand with concerns over use of pesticides, especially certain categories like the neonicotinoids, and the realization that both our food base and health are being compromised. Interestingly, the pollinator crisis focuses on two flash points in our psyche: 'the bee' and 'our health'. The bee (at least the bumble bee) is a flagship insect, easy to recognize, characteristic and valuable, and something that people can associate with positively (New 2012). Bees are tangible and conceptually accessible, and move insect empathy into the realms seen for attractive birds and mammals. Indeed, some insects do better in likability tests than vertebrate competitors (Barua et al. 2012). Thus, their potential to serve as 'conservation ambassadors' to people when seen fluttering or buzzing across the landscape is great. Nowhere is this more poignant than in the case of large-scale insect spectacles, from Monarch butterfly migration to large light displays from various bioluminescent insects, whether in termite mounds, caves or the forest. The same goes for choruses of singing insects, also usually a sign of a healthy ecosystem, the converse of which is Rachel Carson's (1962) 'Silent Spring'.

\section{Value of protected and green areas for human well-being}

Worldwide, 8 billion people per year visit terrestrial protected areas (PAs) (Balmford et al. 2015). Global gross direct expenditure associated with PA visits, (at 2014 prices, within-country only, and excluding indirect and induced expenditure) is estimated to be $\sim$ US $\$ 600$ billion/year worldwide, and consumer surplus to be $\sim$ US $\$ 250$ billion/year. This number is a magnitude greater than the cost of maintaining PAs, which is only $\sim \$ 10$ billion per year (McCarthy et al. 2012). Indeed, McCarthy et al. (2012) suggest that the total cost for biodiversity conservation is small relative to the value of the potential goods and services that biodiversity provides, equivalent to $1-4 \%$ of the estimated net value of ecosystem services that are lost per year, estimated at \$2-6.6 trillion. The point here is that nature is providing enjoyment, and, as a consequence, human well-being. In turn, this opens 
up awareness to nature's organisms of all sizes, including insects, which most of the time most people have not enough time in their busy schedule even to notice. This view fits well with the idea that ecosystem services should be seen as those ecological processes and their effects that humans appreciate i.e. value comes from appreciation (Gunton et al. 2017).

Urban parks, botanical gardens, and dedicated insect reserves, especially in Japan (Simaika and Samways 2008), also play an important role for human well-being (Lemelin 2012) and are important arenas for informal learning (Sellmann and Bogner 2013). Large charismatic insects like dragonflies, called Water Dancers for public appeal (Willis and Samways 2011), have been very popular subjects in recreation and tourism, also at botanical gardens (van der Hoek 2015).

These benefits suggest gross under-investment in conservation areas, whether wild PAs or nearby urban parks and gardens. If properly invested into, protected and green areas could yield even greater returns and safeguard, at least in part, vital ecosystem services and processes, at local to larger spatial scales. One extensive botanical garden in the Cape Floristic Region biodiversity hotspot, and dedicated to indigenous fynbos plant conservation, is one of the most visited botanical gardens globally. It has wild areas within it, and has higher insect diversity than either the urban and, perhaps surprisingly, the natural matrix (Pryke and Samways 2009).

The sheer number of people visiting PAs implies that there is no dichotomy of values, as people obviously are willing to spend on nature, and they feel good by visiting these areas. Rather the challenge is the measure of governments' political will and priority to conserve nature (Weinstein et al. 2015). The loss of vital ecosystem services is not just a moral issue, but also one of significant negative effects on human well-being (Balmford et al. 2002). Accordingly, insect conservation, whether for the utilitarian need of securing our food base or for human well-being, as well as for its intrinsic value, should be high on political agendas.

\section{Challenges beyond our control overpower our individual values}

In surveys of British nationals, Park et al. (2001) found that people had relatively high awareness of global environmental issues. While concern for the environment was also high, environmentally friendly behavior was far lower than concern for the environment. This is evidence for the intentionbehaviour gap (Fig. 1) (Kollmuss and Agyeman 2002). This concept suggests that while individuals may hold high values (e.g. intrinsic), their actions (behaviours) are not environmentally friendly, regardless of the consequence.

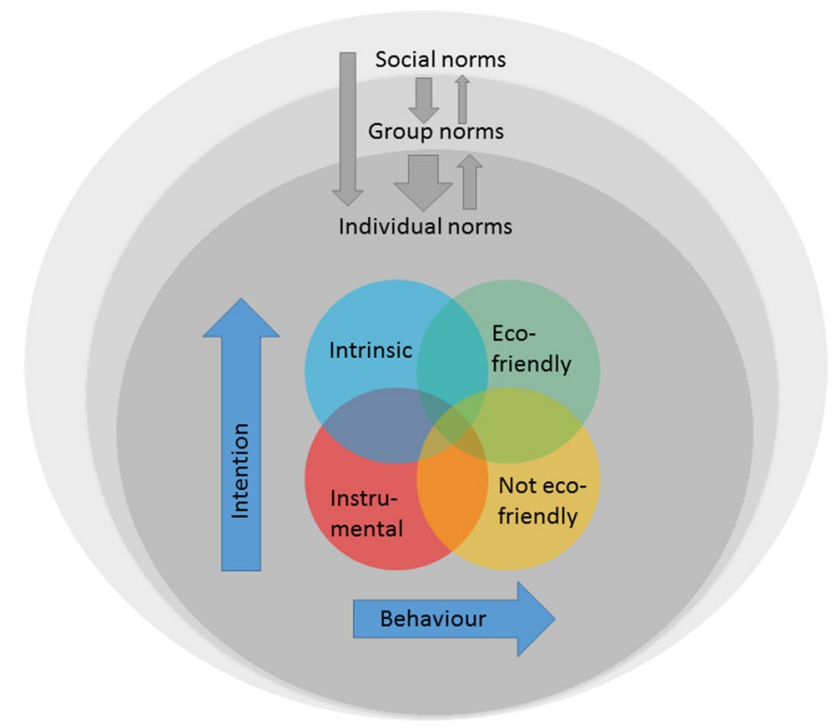

Fig. 1 Hypothetical decision-making framework of individuals, e.g. when purchasing an eco-friendly product. Social and group norms, underlie individual norms (grey spaces), and may be clearly defined in one's mind or not. An individual's values may be high (intrinsic), but the person may not necessarily make an environmentally friendly decision. This is termed the intention-behaviour gap (Blake 1999; Kollmuss and Agyeman 2002). The overlapping spaces between the intention and behaviour circles are the areas that need input from conservation psychology

Given the decline in insects and ecosystem services (Darwall et al. 2012; Gerlach et al. 2012), it is critical that the need for insect conservation effectively elicits both financial and non-financial support from the public, as the Xerces Society (based in the USA), BugLife (UK) and Butterfly Conservation (UK and Europe) do. The very positive outcomes from the activities of these organizations, interestingly, contrasts with the way many individuals respond to environmental issues, like climate change and the less likely they are to feel responsible for global warming (Kellstedt et al. 2008). The reasons for this are complex and multifaceted, but it seems at least in part that insects are more tangible and immediate, and are items that we all have experienced, both good and bad, in our childhood.

As regards climate change and moral judgement, which together serve as a model for people's responses to global conservation issues at large, human moral judgment is not well equipped to identify climate change as an important moral imperative (Markowitz and Shariff 2012). Climate change is a nebulous, complex, large-scale, and an unintentionally caused phenomenon that does not motivate urgent action the way other moral imperatives do. This may well be changing in response to so many climate-triggered and huge impacts on people's living space, support structures, and well-being in many parts of the world in recent times. All of this, of course, assumes that politicians and policy 
Table 2 Summary of psychological challenges posed as suggested by (Markowitz and Shariff 2012), and strategies or solutions for communicators to bolster the recognition of global threats to biodiversity as a moral imperative

\begin{tabular}{lll}
\hline Nr. & Challenges & Strategies/solutions \\
\hline 1 & Abstractness and cognitive complexity & Use existing moral values \\
2 & The blamelessness of unintentional action & Burdens versus benefits \\
3 & Guilty bias & Emotional carrots, not sticks \\
4 & Uncertainty breeds wishful thinking & Be wary of intrinsic motivators \\
5 & Moral tribalism & Expand group identity \\
6 & Long time horizons and faraway places & Highlight positive social norms \\
\hline
\end{tabular}

makers show more accountability in linking anthropogenic climate change with the increasingly major and frequent weather events.

Markowitz and Shariff (2012) give six reasons why climate change does not register in our minds, and provide six possible solutions, summarized in Table 2. Compellingly, they warn that pushing action on climate change as good business may backfire. Also, using economic incentives as a motivation creates a conflict between the negatively related values of materialism and environmentalism (Brown and Kasser 2005). The promotion of extrinsic (i.e. materialistic) values inhibits individuals from developing non-materialistic values, which crowd out and extinguish any previous nonmaterialistic values. When the extrinsic factor is removed, so the incentive to continue with the behaviour for its own sake also goes. The point is that considerations of right and wrong are powerful motivators of behaviour. In short, personal moral norms play a critical role in driving pro-social and pro-environmental behaviour (Stern 2000).

It seems that we view such a large-scale but a nebulous phenomenon as climate change not only as an 'inconvenient truth', but also, strangely, not in our back yard. In contrast, the pollinator crisis is also large-scale, but tangible. We know instinctively that bees are good creatures, and besides, we can see and touch them: 'Yet bad people are messing with bees' brains (Klein et al. 2017) and they are being slaughtered right before our eyes, taking away some of our food, and worse still, poisoning us too... how dare they!'

The onus is therefore on conservation practitioners and policy makers to tap into these insights to tackle the challenge of insect conservation. This is now taking place where insect services are being promoted alongside the conservation of nature through, for example, agro-ecology, which looks after pollinators as well as other service providers such as biological control agents. Yet conservation of an insect service does not always equate with the conservation of rare and threatened insects per se, with human mitigation for wildlife-friendly service provision sometimes at odds with insect conservation for its own sake (Kleijn et al. 2015).

Although the other major threats to biodiversity, such as habitat loss, invasion by alien species, and pollution are tangible challenges, these have become problems on a global scale, as with climate change (Gerlach et al. 2012). These impacts are also often adversely synergistic with climate change, and for rare insects, habitat loss and climate change are a 'deadly anthropogenic cocktail' (Travis 2003). The threats to biodiversity are complex, large-scale, and unintentional, and so elicit the same kind of individual behaviour and moral judgement as does climate change, with a decreasing concern for environmental conservation, at least up to 2013 (Mccallum and Bury 2013). There are however, notable exceptions, with an increase in single-species conservation awareness and recognition that the protection of specific habitat types is both tangible and essential (Gascon et al. 2015).

There are two areas where insect conservation awareness has increased greatly in recent years. These are the IUCN (International Union for the Conservation of Nature) Red List (http://www.iucnredlist.org) and citizen science. Once an insect species is on the Red List, it immediately becomes iconic. An insect species that few people might actually have seen in the wild suddenly becomes high profile and often becomes the subject of conservation action once it is on the Re List. This is despite the Red List not actually being a priority list for action. Red Listed species also help protect certain landscapes as their presence, especially when there are other iconic/rare/Red Listed species at the same locality, feeds into irreplaceability of that locality.

Citizen science (the involvement of informed and enthusiastic sectors of the public for recording the distribution of species and engaging in their conservation) can feed into developing national insect strategies (Roy et al. 2015). However, there are some important prerequisites for effective citizen science. Among them is the availability good identification guides and common names for species, both of which are necessary, alongside expert support, for identification of the focal species (Le Féon et al. 2016). Image capture, especially using readily accessible cellular phones, is also playing a huge role in increasing insect awareness, with an image of an insect equaling that of an elephant in size.

Citizen science has greatly improved our understanding of butterflies in the USA (Lewandowski and Oberhauser 2017), stag beetles in Europe (Zapponi et al. 2017) and pollinators in the USA (Domroese and Johnson 2017), to name 
just a few. The point is that all these extra eyes and hands really widen the net for capturing knowledge on insects, as well as increase awareness of insects in our world-view i.e. rescuing the extinction of experience. The people and the outcomes of a citizen science programme also provide much greater lobbying power with which to influence policy makers. This positive feedback loop also leads to valuable new strategies such as Natural England's Conservation Strategy for the twenty-first Century (Conservation 21 2016), where the interrelationship between people and insects (and other biodiversity) is promoted for the benefit of all.

Acknowledgements JS acknowledges funding from the National Research Foundation (South Africa), and MS from the Mondi Group. We thank two anonymous referees for insightful comments.

Open Access This article is distributed under the terms of the Creative Commons Attribution 4.0 International License (http://creativeco mmons.org/licenses/by/4.0/), which permits unrestricted use, distribution, and reproduction in any medium, provided you give appropriate credit to the original author(s) and the source, provide a link to the Creative Commons license, and indicate if changes were made.

\section{References}

Balmford A, Clegg L, Coulson T, Taylor J (2002) Why conservationists should heed Pokémon. Science 295:2367. https://doi.org/10.1126/ science.295.5564.2367b

Balmford A, Green JMH, Anderson M et al (2015) Walk on the wild side: estimating the global magnitude of visits to protected areas. PLoS Biol 13:1-6. https://doi.org/10.1371/journal.pbio.1002074

Barua M, Gurdak DJ, Ahmed RA, Tamuly J (2012) Selecting flagships for invertebrate conservation. Biodivers Conserv 21:1457-1476. https://doi.org/10.1007/s10531-012-0257-7

Batavia C, Nelson MP (2017) For goodness sake! What is intrinsic value and why should we care? Biol Conserv 209:366-376. https ://doi.org/10.1016/j.biocon.2017.03.003

Bennett EM (2017) Changing the agriculture and environment conversation. Nat Ecol Evol 1:1-2. https://doi.org/10.1038/s4155 9-016-0018

Blake J (1999) Overcoming the "value-action gap" in environmental policy: tensions between national policy and local experience. Local Environ 4:257-278. https://doi.org/10.1080/1354983990 8725599

Brown KW, Kasser T (2005) Are psychological and ecological wellbeing compatible? The role of values, mindfulness, and lifestyle. Soc Indic Res 74:349-368. https://doi.org/10.1007/s1120 5-004-8207-8

Burls A (2007) People and green spaces: promoting public health and mental well-being through ecotherapy. J Public Ment Health 6:24-39. https://doi.org/10.1108/17465729200700018

Cafaro P (2015) Three ways to think about the sixth mass extinction. Biol Conserv 192:387-393. https://doi.org/10.1016/j.bioco n.2015.10.017

Carson R (1962) Silent spring. Fawcett Publications, Greenwich

Chan KMA, Balvanera P, Benessaiah K et al (2016) Opinion: why protect nature? Rethinking values and the environment. Proc Natl Acad Sci USA 113:1462-1465. https://doi.org/10.1073/ pnas. 1525002113
Clark NE, Lovell R, Wheeler BW et al (2014) Biodiversity, cultural pathways, and human health: a framework. Trends Ecol Evol 29:198-204. https://doi.org/10.1016/j.tree.2014.01.009

Clayton S, Myers G (2009) Conservation psychology. Understanding and promoting human care for nature. Wiley, Oxford

Conservation 21 (2016) Natural England's conservation strategy for the 21st century. http://www.gov.uk/natural-england

Costanza R, Fioramonti L, Kubiszewski I (2016) The UN Sustainable Development Goals and the dynamics of well-being. Front Ecol Environ 14:59-59. https://doi.org/10.1002/fee.1231

Darwall W, Seddon M, Clausnitzer V, Cumberlidge N (2012) Freshwater invertebrate life. In: Collen B, Böhm M, Kemp R, Baillie JE. (eds) Spineless: status and trends of the world's invertebrates. Zoological Society of London, London, pp 26-33

Domroese MC, Johnson EA (2017) Why watch bees? Motivations of citizen science volunteers in the Great Pollinator Project. Biol Conserv 208:40-47. https://doi.org/10.1016/j.biocon.2016.08.020

Ferrier S, Ninan KN, Leadley P et al (eds) (2016) IPBES 2016: summary for policymakers of the methodological assessment report of the intergovernmental science-policy platform on biodiversity and ecosystem services (IPBES) on scenarios and models of biodiversity and ecosystem services. Bonn

Gascon C, Brooks TM, Contreras-Macbeath T et al (2015) The importance and benefits of species. Curr Biol 25:R431-R438. https://doi.org/10.1016/j.cub.2015.03.041

Gerlach J, Hoffman Black S, Hochkirch A et al (2012) Terrestrial invertebrate life. In: Collen B, Böhm M, Kemp R, Baillie JE. (eds) Spineless: status and trends of the world's invertebrates. Zoological Society of London, London, pp 46-58

Gunton RM, van Asperen EN, Basden A et al (2017) Beyond ecosystem services: valuing the invaluable. Trends Ecol Evol 32:249_ 257. https://doi.org/10.1016/j.tree.2017.01.002

Hallmann CA, Sorg M, Jongejans E et al (2017) More than 75 percent decline over 27 years in total flying insect biomass in protected areas. PLoS ONE 12:e185809. https://doi.org/10.1371/ journal.pone.0185809

Harari YN (2016) Homo Deus: a brief history of tomorrow. Vintage, London

Hoot RE, Friedman H (2011) Connectedness and environmental behavior: sense of interconnectedness and pro-environmental behavior. Int J Transpers Stud 30:89-100

IEEP, Collingwood Environmental Planning, ESP, ICLEI, Luke, Milieu and WWF (2016) The health and social benefits of nature and biodiversity protection-background report for a workshop by the European commission (ENV.B.3/ETU/2014/0039) and hosted by the committee of the regions (27-28 January 2016). Institute for European Environmental Policy, London

Justus J, Colyvan M, Regan H, Maguire L (2009) Buying into conservation: intrinsic versus instrumental value. Trends Ecol Evol 24:187-191. https://doi.org/10.1016/j.tree.2008.11.011

Kahn P, Kellert S (2002) Children and nature: psychological, sociocultural and evolutionary investigations. The MIT Press, Massachusetts

Kellert SR (1993) The biological basis for human values of nature. In: Kellert S, Wilson EO (eds) The biophilia hypothesis. Island Press, Washington, D.C., pp 42-69

Kellstedt PM, Zahran S, Vedlitz A (2008) Personal efficacy, the information environment, and attitudes toward global warming and climate change in the United States. Risk Anal 28:113-126. https://doi.org/10.1111/j.1539-6924.2008.01010.x

Kleijn D, Winfree R, Bartomeus I et al (2015) Delivery of crop pollination services is an insufficient argument for wild pollinator conservation. Nat Commun 6:7414. https://doi.org/10.1038/ ncomms 8414 
Klein S, Cabirol A, Devaud JM et al (2017) Why bees are so vulnerable to environmental stressors. Trends Ecol Evol 32:268-278. https://doi.org/10.1016/j.tree.2016.12.009

Kollmuss A, Agyeman J (2002) Mind the gap: why do people behave environmentally and what are the barriers to pro-environmental behaviour. Environ Educ Res 8:239-260. https://doi. org/10.1080/1350462022014540

Le Féon V, Henry M, Guilbaud L et al (2016) An expert-assisted citizen science program involving agricultural high schools provides national patterns on bee species assemblages. J Insect Conserv 20:905-918. https://doi.org/10.1007/s1084 1-016-9927-1

Lemelin RH (ed) (2012) The management of insects in recreation and tourism. Cambridge University Press, Cambridge

Lewandowski EJ, Oberhauser KS (2017) Butterfly citizen scientists in the United States increase their engagement in conservation. Biol Conserv 208:106-112. https://doi.org/10.1016/j.bioco n.2015.07.029

Markowitz E, Shariff A (2012) Climate change and moral judgement. Nat Clim Chang 2:243-247. https://doi.org/10.1038/nclimate13 78 doi

Martín-López B, Montes C (2015) Restoring the human capacity for conserving biodiversity: a social-ecological approach. Sustain Sci 10:699-706. https://doi.org/10.1007/s11625-014-0283-3

Mccallum ML, Bury GW (2013) Google search patterns suggest declining interest in the environment. Biodivers Conserv 22:1355-1367. https://doi.org/10.1007/s10531-013-0476-6

McCarthy DP, Donald PF, Scharlemann JP, Buchanan GM et al (2012) Financial costs of meeting global biodiversity conservation targets: current spending and unmet needs. Science 338:946-949

Mitchell R, Popham F (2008) Effect of exposure to natural environment on health inequalities: an observational population study. Lancet 372:1655-1660. https://doi.org/10.1016/S0140-6736(08)61689-X

Navarro LM, Pereira HM (2012) Rewilding abandoned landscapes in Europe. Rewilding Eur Landscapes 15:900-912. https://doi. org/10.1007/978-3-319-12039-3 1

New TR (ed) (2012) Insect conservation: past, present and prospects. Springer, Dordrecht

Nilsson K, Sangster M, Gallis C et al (eds) (2010) Forests, trees and human health. Springer, New York

Norton BG (2000) Biodiversity and environmental values: in search of a universal earth ethic. Biodivers Conserv 9:1029-1044. https:// doi.org/10.1023/A:1008966400817

Park A, Curtice J, Thomson K et al (2001) British social attitudes: the 18 th report. Sage, London

Pearson RG (2016) Reasons to Conserve Nature. Trends Ecol Evol 31:366-371. https://doi.org/10.1016/j.tree.2016.02.005

Potts SG, Biesmeijer JC, Kremen C et al (2010) Global pollinator declines: trends, impacts and drivers. Trends Ecol Evol 25:345353. https://doi.org/10.1016/j.tree.2010.01.007

Pryke JS, Samways MJ (2009) Recovery of invertebrate diversity in a rehabilitated city landscape mosaic in the heart of a biodiversity hotspot. Landsc Urban Plan 93:54-62. https://doi.org/10.1016/j. landurbplan.2009.06.003

Rolston H III (1994) Conserving natural value. Columbia University Press, New York

Roskos-Ewoldsen DR, Yu JH, Rhodes N (2004) Fear appeal messages affect accessibility of attitudes toward the threat and adaptive behaviors. Commun Monogr 71:49-69. https://doi. org/10.1080/0363452042000228559

Roy DB, Ploquin EF, Randle Z, Risely K, Botham MS et al (2015) Comparison of trends in butterfly populations between monitoring schemes. J Insect Conserv 19:313-324
Samways MJ (2007) Rescuing the extinction of experience. Biodivers Conserv 16:1995-1997. https://doi.org/10.1007/s1053 1-006-9144-4

Samways MJ (2015) Future-proofing insect diversity. Curr Opin Insect Sci 12:71-78. https://doi.org/10.1016/j.cois.2015.09.008

Samways MJ (2017) Reconciling ethical and scientific issues in insect conservation. In: Foottit RG, Adler PH (eds) Insect biodiversity: science and society, 2nd edn. Wiley, New York, pp 747-766

Samways M, Böhm M (2012) Hidden in plain view: effective invertebrate conservation for our future world. In: Collen B, Böhm M, Kemp R, Baillie J (eds) Spineless: status of the world's invertebrates. Zoological Society of London, London, pp 72-85

Schlegel J, Breuer G, Rupf R (2015) Local insects as flagship species to promote nature conservation? A survey among primary school children on their attitudes toward invertebrates. Anthrozoos 28:229-245. https://doi.org/10.1080/08927936.2015.11435399

Sellmann D, Bogner FX (2013) Climate change education: quantitatively assessing the impact of a botanical garden as an informal learning environment. Environ Educ Res 19:415-429

Simaika JP, Samways MJ (2008) Valuing dragonflies as service providers. In: Córdoba-Aguilar A (ed) Dragonflies: model organisms for ecological and evolutionary research. Oxford University Press, Oxford, pp 109-123

Simaika JP, Samways MJ (2010) Biophilia as a universal ethic for conserving biodiversity. Conserv Biol 24:903-906. https://doi.org/10 $.1111 / \mathrm{j} .1523-1739.2010 .01485 . \mathrm{x}$

Soga M, Gaston KJ (2016) Extinction of experience: the loss of humannature interactions. Front Ecol Environ 14:94-101. https://doi. org/10.1002/fee. 1225

Stern PC (2000) Toward a coherent theory of environmentally significant behavior. J Soc Issues 56:407-424. https://doi. org/10.1111/0022-4537.00175

Suh AN, Samways MJ (2001) Development of a dragonfly awareness trail in an African botanical garden. Biol Conserv 100(3):345-353

Travis JMJ (2003) Climate change and habitat destruction: a deadly anthropogenic cocktail. Proc Biol Sci 270:467-473. https://doi. org/10.1098/rspb.2002.2246

van der Hoek Y (2015) Tropical botanical gardens play an underemphasized role in animal conservation. Braz $\mathbf{J}$ Nat Conserv 13:88-92. https://doi.org/10.1016/j.ncon.2015.03.004

Walker-Springett K, Jefferson R, Böck K et al (2016) Ways forward for aquatic conservation: applications of environmental psychology to support management objectives. J Environ Manag 166:525-536. https://doi.org/10.1016/j.jenvman.2015.11.002

Weinstein N, Rogerson M, Moreton J et al (2015) Conserving nature out of fear or knowledge? Using threatening versus connecting messages to generate support for environmental causes. J Nat Conserv 26:49-55. https://doi.org/10.1016/j.jnc.2015.04.002

Willis CK, Samways MJ (2011) Water dancers of South Africa's National Botanical Gardens. SANBI Biodiversity Series 21. South Africa's National Botanical Gardens, Pretoria

Zapponi L, Cini A, Bardiani M et al (2017) Citizen science data as an efficient tool for mapping protected saproxylic beetles. Biol Conserv 208:139-145. https://doi.org/10.1016/j.biocon.2016.04.035

Zylstra MJ, Knight AT, Esler KJ, Le Grange LLL (2014) Connectedness as a core conservation concern: an interdisciplinary review of theory and a call for practice. Springer Sci Rev 2:119-143. https ://doi.org/10.1007/s40362-014-0021-3 